Journal of Animal and Veterinary Advances 11 (17): 3228-3233, 2012

ISSN: $1680-5593$

(C) Medwell Journals, 2012

\title{
Prediction of Ruminal Methane Production from Cattle
}

\author{
${ }^{1}$ Sang-Moon Lee, ${ }^{1}$ Jin-Suk Jeong, ${ }^{2}$ Sang-Cheol Lee, ${ }^{2}$ Kyu-Hyun Park and ${ }^{1}$ Seongwon Seo \\ ${ }^{1}$ Department of Animal Biosystem Sciences, Chungnam National University, \\ 305-764 Daejeon, Korea \\ ${ }^{2}$ National Institute of Animal Science, Rural Development Administration, \\ 441-706 Suwon, Republic of Korea
}

\begin{abstract}
Methane, one of the major greenhouse gases is produced primarily from cattle among livestock. Many researches have been conducted to reduce methane production and also to develop methods and/or equations to predict methane production in cattle. The objectives of this study were thus to construct a database containing experimental observations of methane production from cattle and to develop equations that predict methane production by cattle accurately. The database developed in this study contains experimental observations from the research articles published in the Journal of Dairy Science, Journal of Animal Science, Animal Feed Science and Technology, Canadian Journal of Animal Science, International Congress Series and Journal of Nutrition from 1964 till 2009. A total of 350 treatment means from 75 studies were obtained from the scientific journal articles that were found by searching for with methane and cattle as keywords. There were different methods measuring methane production; a chamber system, indirect respiratory hood, Sulfur hexafluoride $\left(\mathrm{SF}_{6}\right)$ and stoichiometric calculation. Only measured data were used in the subsequent analysis. Consequently the actual database used for the analysis is composed of a total of 256 treatment means from 57 studies. The types of animal in the database were 110 lactating dairy cows, 12 non-lactating dairy cows, 47 heifers, 65 steers, 10 calves, 10 bulls and 2 mixed. The mean $( \pm \mathrm{SD})$ methane $\left(\mathrm{g} \mathrm{day}^{-1}\right)$ methane $\left(\mathrm{Mcal} \mathrm{day}^{-1}\right)$ and methane $(\mathrm{GE} \%)$ of the data were $204.50( \pm 104.22), 2.76( \pm 1.38)$ and $5.56( \pm 1.87)$, respectively. Among the variables tested, $\mathrm{DMI}(\mathrm{kg})$ or $\mathrm{NDF}$ intake $(\mathrm{NDFI}, \mathrm{kg})$ was the most significant single variable that correlates with methane production. Using a random coefficient model with study as a random effect, researchers obtained $-24.27( \pm 17.76)+13.93( \pm 1.68) \mathrm{DMI}(\mathrm{kg})+0.57( \pm 0.20) \mathrm{FpDM}+8.43( \pm 4.16) \mathrm{NDFI}(\mathrm{kg})(\mathrm{n}=145,-2$ Res $\log$ likelihood $=1434.9$ ) for predicting methane production $(\mathrm{g})$. Using a simple linear regression, the best equation was $\mathrm{CH}_{4}(\mathrm{~g})=-18.53( \pm 14.90)+11.89( \pm 1.50) \mathrm{DMI}(\mathrm{kg})+0.49( \pm 0.18) \mathrm{FpDM}+14.19( \pm 3.77) \mathrm{NDFI}(\mathrm{kg})\left(\mathrm{R}^{2}=0.84\right.$, root mean square error $=42.25$ ). Although, DMI and NDFI are inherently correlated, a single variable was not sufficient to explain the variations in methane production of cattle. When both NDFI and DMI were present in the model statement type of animal or method of methane measurement was no longer significant. The results from this study suggest that methane production from cattle can be predicted accurately with DMI and NDFI. More research however is needed to improve accuracy of the model predictions.
\end{abstract}

Key words: Methane, modeling, cattle, animal, green house, bulls

\section{INTRODUCTION}

The Greenhouse Gas (GHG) emissions have become one of the major concerns in the modern human society due to their effects on global climate change. It was estimated that the average temperature of the earth could increase $3.6^{\circ} \mathrm{C}$ by the year 2100 which may possibly increase a sea level $>0.9 \mathrm{~m}$ (Garton and Birkenholz, 1998). The primary $\mathrm{GHG}$ emitted by agriculture are methane $\left(\mathrm{CH}_{4}\right)$ and Nitrous Oxide $\left(\mathrm{N}_{2} \mathrm{O}\right)$. Enteric methane production, especially is a major contributor to GHG emissions by cattle (Kebreab et al., 2006) and also represents a loss of nutrient that can be used for animal production otherwise. Enteric methane production varies between $2-12 \%$ of gross energy intake (Johnson and Johnson, 1995).

A recent statistics showed that enteric methane emissions from livestock, mostly cattle, represent about $24 \%$ of the total methane emissions in the US (EPA, 2009). In 2007 , methane emissions from enteric fermentation by beef and dairy cattle were estimated to be 100.2 and 31.9 $\mathrm{Tg} \mathrm{CO}_{2}$ equivalent which contributed 53 and $17 \%$ of the methane emissions from the agriculture sector in the US

Corresponding Author: Seongwon Seo, Department of Animal Biosystem Sciences, Chungnam National University, 305-764 Daejeon, Korea 
(EPA, 2009). Although, the total amount of methane emissions by beef cattle is larger than by dairy cattle, individual dairy cattle produce more methane than beef cattle, primary due to high feed intake and high forage content in a dairy diet (Ellis et al., 2007). In order to find better ways to reduce methane emissions, accurate estimation is a pre-requisite.

The most accurate and reliable way of estimating methane emissions may be to directly measure methane emissions from each cow herd or farm experimentally. Experimental measurement however, requires a large amount of time money and labor and the measurements vary by methods (Grainger et al., 2007). Especially for constructing an inventory of methane production in animal sector and searching for effective mitigation strategies, experimental measurement is not easy to be applied but models can be used without undertaking extensive and costly experiments. In this regards there have been attemps to develop an empirical model for predicting methane production from cattle (Ellis et al., 2007, 2009).

Due to a recent increase in the interest of reducing methane emissions, the number of publications that measure methane production of cattle increases dramatically each year. Thus, there is still a strong rationale for constructing a database that incorporates these recent observations and developing a model to accurately predict methane production based on this accumulated knowledge. The objectives of this study were thus to construct a database containing recent experimental observations of methane production from cattle, to identify the most critical variables related with ruminal methane production and to develop equations that predict ruminal methane production by cattle accurately.

\section{MATERIALS AND METHODS}

Database construction: The database developed in this study contains experimental observations from the research articles published in the Journal of Dairy Science, Journal of Animal Science, Animal Feed Science and Technology, Canadian Journal of Animal Science, International Congress Series and Journal of Nutrition from 1964 till 2009. A total of 350 treatment means from 75 studies were obtained from the scientific journal articles that were found by searching for with methane and (cattle or beef or dairy) as title, topic or keywords. There were different methods measuring methane production among treatment means; 77, 112, 67 and 94 methane measurements were obtained using a chamber system, indirect respiratory hood, Sulfur hexafluoride

$\left(\mathrm{SF}_{6}\right)$ and stoichiometric calculation, respectively. Among these only measured data were used in the following analysis.

Consequently the actual database used for the analysis is composed of a total of 256 treatment means from 57 studies. The types of animal in the database were 110 lactating dairy cows, 12 non-lactating dairy cows, 112 growing heifers or steers, 10 bulls, 10 calves, 2 mixes of beef and dairy cattle. The mean $( \pm \mathrm{SD})$ of methane $\left(\mathrm{g} \mathrm{day}^{-1}\right)$, methane $\left(\mathrm{Mcal}\right.$ day $\left.^{-1}\right)$ and methane $(\mathrm{GE} \%)$ of the database were $204.50( \pm 104.22), 2.76( \pm 1.38)$ and $5.56( \pm 1.87)$, respectively. The detailed descriptive statistics of the database is shown in Table 1.

Model development: Before identifying significant variables for predicting methane production, a total of 12 outliers were omitted from the database. Outliers were determined using the difference in fits statistic (DFFITS). Data points with absolute values of DFFITS $\geq 0.4$ which is a conservative value based on Neter et al. (1996) were omitted. When more than one absolute value of DFFITS was $>0.4$, data corresponding to the largest value was omitted first and the model was refitted to examine whether any other absolute value of DFFITS remained $\geq 0.4$. The procedure continued until no apparent outlier was observed. To prevent erroneously removing acceptable observations data that previously were omitted were added back sequentially to the model and re-evaluated. As a result, a total of 244 treatment means from 57 studies were used for subsequent analysis.

The initial independent variables used for explaining the variations in methane production $\left(\mathrm{g} \mathrm{day}^{-1}\right)$ were Dry Matter Intake (DMI, kg) Body Weight (BW, kg), DMI as

Table 1: Descriptive statistics for the database used for developing equations

\begin{tabular}{|c|c|c|c|c|c|c|}
\hline$\underline{\text { Parameters }}$ & $\mathrm{N}$ & Mean & $\mathrm{SD}$ & Median & Max. & Min. \\
\hline \multicolumn{7}{|l|}{ Animal inputs } \\
\hline BW (kg) & 253 & 452.23 & 157.65 & 488.00 & 740.00 & 130.00 \\
\hline DMI (kg day $\left.{ }^{-1}\right)$ & 251 & 10.950 & 5.8300 & 8.8600 & 26.500 & 1.3500 \\
\hline DMI (BW\%) & 251 & 2.3600 & 0.7600 & 2.3000 & 4.5300 & 0.9000 \\
\hline GEI (Mcal day $\left.{ }^{-1}\right)$ & 195 & 49.950 & 25.670 & 43.260 & 6.9400 & 119.91 \\
\hline Forage (DM\%) & 238 & 66.190 & 26.900 & 74.000 & 100.00 & 2.0000 \\
\hline \multicolumn{7}{|l|}{ Nutrient composition } \\
\hline $\mathrm{DM}(\mathrm{AF} \%)$ & 133 & 570990 & 24.520 & 52.100 & 97.800 & 22.300 \\
\hline CP (DM\%) & 195 & 15.840 & 3.7000 & 15.900 & 28.880 & 5.1000 \\
\hline $\mathrm{EE}(\mathrm{DM} \%)$ & 95 & 4.0300 & 2.8700 & 3.0000 & 16.400 & 0.5000 \\
\hline Ash (DM\%) & 92 & 7.5400 & 2.0600 & 7.2200 & 12.100 & 4.2800 \\
\hline CF (DM\%) & 33 & 13.430 & 7.7000 & 16.500 & 30.400 & 0.4000 \\
\hline NDF (DM\%) & 150 & 41.160 & 14.810 & 37.700 & 78.400 & 1.5000 \\
\hline $\mathrm{ADF}(\mathrm{DM} \%)$ & 168 & 23.830 & 10.920 & 21.480 & 53.500 & 0.4000 \\
\hline \multicolumn{7}{|l|}{ Methane production } \\
\hline Methane $\left(\mathrm{g} \mathrm{day}^{-1}\right)$ & 244 & 202.50 & 104.22 & 186.16 & 466.97 & 1.7300 \\
\hline Methane (Mcal day $\left.{ }^{-1}\right)$ & 237 & 2.760 & 1.3800 & 2.5200 & 6.2000 & 0.0200 \\
\hline Methane (GE\%) & 202 & 5.560 & 1.8700 & 5.8400 & 10.370 & 0.2800 \\
\hline
\end{tabular}


a percentage of $\mathrm{BW}(\mathrm{DM} \mathrm{pBW}, \%)$, forage as a percentage of dietary DM (FpDM, \%), Crude Protein (CP, DM\%), CP Intake (CPI, kg), Neutral Detergent Fiber (NDF, DM\%), NDF Intake (NDFI, kg), Acid Detergent Fiber $(\mathrm{ADF}, \mathrm{DM} \%)$ and $\mathrm{ADF}$ Intake (ADFI, kg). Ether Extract (EE, DM\%) and ash (DM\%) were excluded from the candidate variable list because a small number of observed means reported these values. Among these variables, predictive variables that significantly and sufficiently explained the variations in each dependent variable were selected using step-wise regression.

Statistical analysis: The regression equation was developed in two phases. In the first phase, a random coefficients model was used using the MIXED procedure of SAS (2002) with study as a random variable to identify independent variables that were statistically significant $(p<0.05)$. Among the acceptable regression models that had a linear combination of significant fixed effect variables, a model that had the lowest value of -2 restricted log likelihood, Akaike's Information Criterion (AIC), the corrected AIC (AICC) and Schwarz's Bayesian Criterion (SBC) was selected. The lowest value of those criteria above indicates a better model considering the number of observations, the number of parameters and the maximum likelihood estimates.

In the second phase, the parameters of the variables in the best model to predict methane production, identified in the first phase were estimated by fitting the prediction equation to a multiple regression model using GLM procedure of SAS (SAS Institute, Inc.).

\section{RESULTS AND DISCUSSION}

Among the variables tested, DMI, NDFI and ADFI were the most significant single variable that correlates with methan production. DMI alone explained $76.7 \%$ of the variations in methane production (Fig. 1). It is

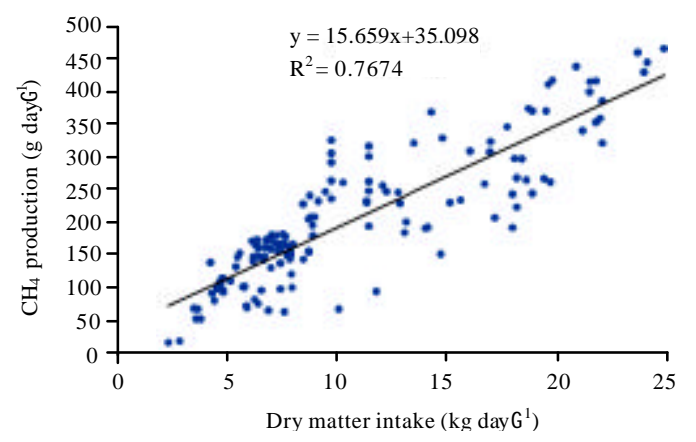

Fig. 1: Linear relationship of $\mathrm{CH}_{4}$ production $\left(\mathrm{g}\right.$ day $\left.{ }^{-1}\right)$ with dry matter intake $\left(\mathrm{kg}\right.$ day $\left.^{-1}\right)$ consistent with other previous reports (Axelsson, 1949; Ellis et al., 2007; Kriss, 1930; Mills et al., 2003). DMI and Metabolisable Energy (ME) intake $\left(\mathrm{MJ}^{\mathrm{day}}{ }^{-1}\right.$ ) have been recognized as the most significant variable that affects ruminal methane production (Ellis et al., 2007; Mills et al., 2003). In this study however, researchers omitted $\mathrm{ME}$ intake from the candidate variables because $\mathrm{ME}$ content of a diet is normally calculated from digestible energy content of the diet $(\mathrm{NRC}, 2000,2001)$ and $\mathrm{ME}$ is the amount of energy subtracting energy losses via urine and gas from digestible energy and it may be double accounting if $\mathrm{ME}$ intake is used for predicting methan production.

Out of a total of 8 candidate variables, the first phase of analysis using step-wise regression and a random coefficient model selected combinations of DMI, NDFI, BW, DMIpBW and FpDM. The amount of ADF and ADFI also showed significant effects on ruminal methane production and thus combinations with $\mathrm{ADF}$ instead of NDF were also possible. However, at the second phase of analysis using GLM procedure it turned out that ADFI was not significant while NDFI was a significant variable for predicting methane production in both MIXED and GLM procedure. NDF represents the total amount of fiber (i.e., hemicellulose, cellulose and lignin) while ADF contains cellulose and lignin without hemicellulose (Van Soest, 1994). Methane production may be related with $\mathrm{ADF}$ which is related with digestibility of forage (Rohweder et al., 1978). However, digestibiliyt of fiber is more related with the amount of lignin in the fiber (Weiss, 1993) which was not normally measured in the past, neither NDF nor ADF was a significant variable for estimating rate of passge of forage out of the rumen (Seo et al., 2006) and NDF is correlated with ADF and is more widely measured in the field. Moreover, since the objective of this study was to develop a prediction equation for ruminal methane production in the field and the significance of a variable in GLM Model is more important, researchers decided to select NDFI as a variable for the next analysis. Nevertheless, the equations developed using variable combinations with ADFI are also shown in Table 2.

The selected variables (DMI, NDFI, BW, DMIpBW and $\mathrm{FpDM}$ ) were significantly and linearly related with ruminal methane production. Each of DMI, NDFI, BW and DMIpBW explained the variations in observed methane production by $76.7,74.9,47.8$ and $43.9 \%$, respectively (Fig. 1-4). FpDM alone was not a significant variable (Fig. 5) however, adding FpDM in the model statement can explain more variations and FpDM became statistically significant $(\mathrm{p}<0.05)$. Using a random coefficient model with study as a random effect, 


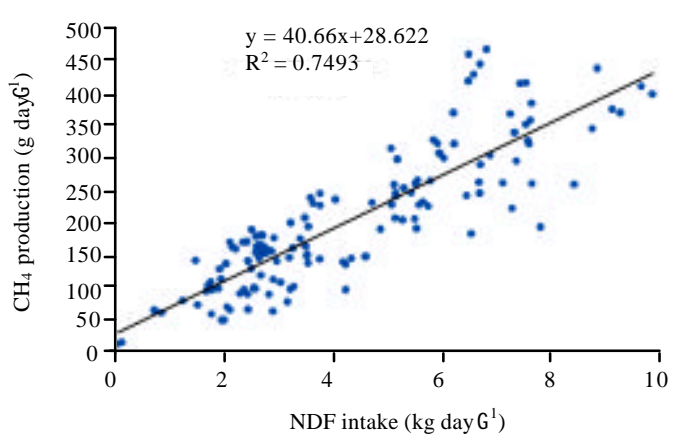

Fig. 2: Relationship of $\mathrm{CH}_{4}$ production $\left(\mathrm{g}_{\text {day }}{ }^{-1}\right)$ with neutral detergent fiber intake $\left(\mathrm{kg}_{\text {day }}{ }^{-1}\right)$

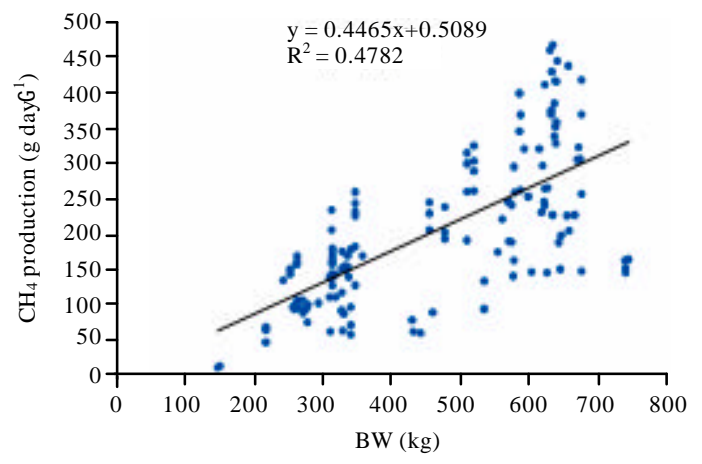

Fig. 3: Relationship of $\mathrm{CH}_{4}$ production $\left(\mathrm{g}\right.$ day $\left.{ }^{-1}\right)$ with animal body weight $(\mathrm{kg})$

Table 2: List of equations developed for predicting methane production of cattle with acid detergent fiber inatke

\begin{tabular}{|c|c|c|c|c|c|}
\hline Equation No. & Variable $^{\mathrm{a}}$ & $p$-value & $\mathrm{n}$ & $\mathrm{R}^{2}$ & $\mathrm{RMSE}^{\mathrm{b}}$ \\
\hline \multirow[t]{6}{*}{1} & Intercept & 0.12440 & 161 & 0.8284 & 44.26 \\
\hline & DMI & $<0.0001$ & & & \\
\hline & ADFI & 0.00220 & & & \\
\hline & FpDM & 0.00550 & & & \\
\hline & DMПрBW & 0.01310 & & & \\
\hline & $\mathrm{ADF}$ & 0.11540 & & & \\
\hline \multirow[t]{5}{*}{2} & Intercept & 0.54000 & 161 & 0.8257 & 44.47 \\
\hline & DMI & $<0.0001$ & & & \\
\hline & ADFI & 0.00190 & & & \\
\hline & FpDM & 0.01480 & & & \\
\hline & DMПрBW & 0.02820 & & & \\
\hline \multirow[t]{4}{*}{3} & Intercept & 0.91900 & 220 & 0.7836 & 47.79 \\
\hline & DMI & $<0.0001$ & & & \\
\hline & FpDM & $<0.0001$ & & & \\
\hline & DM!pBW & $<0.0001$ & & & \\
\hline \multirow[t]{3}{*}{4} & Intercept & 0.01680 & 220 & 0.7652 & 49.67 \\
\hline & DMI & $<0.0001$ & & & \\
\hline & FpDM & $<0.0001$ & & & \\
\hline \multirow[t]{4}{*}{5} & Intercept & 0.64920 & 161 & 0.8202 & 45.02 \\
\hline & DMI & $<0.0001$ & & & \\
\hline & FpDM & 0.03480 & & & \\
\hline & DMIpBW & 0.00130 & & & \\
\hline \multirow[t]{4}{*}{6} & Intercept & 0.00620 & 161 & 0.8128 & 45.94 \\
\hline & DMI & $<0.0001$ & & & \\
\hline & FpDM & 0.00440 & & & \\
\hline & $\mathrm{ADF}$ & 0.04560 & & & \\
\hline
\end{tabular}

${ }^{a}$ DMI: Dry Matter Intake, ADFI: Acid Detergent Fiber Intake, FpDM: Forage as a Percentage of Dietary DM, DMIpBW: DMI as a percentage of BW, ADF: Acid Detergent Fiber, ${ }^{b}$ RMSE: Root Mean Square Error

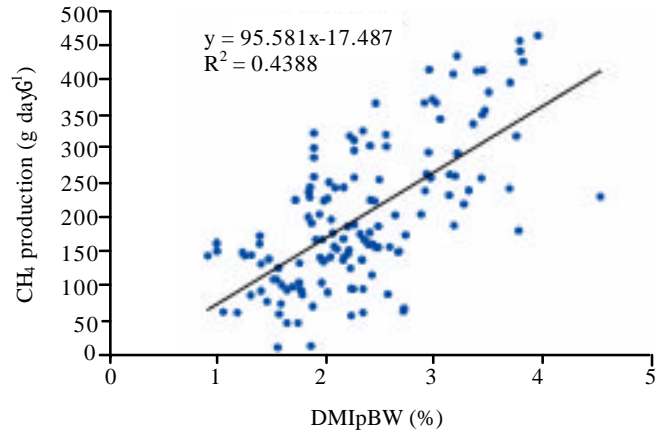

Fig. 4: Relationship of $\mathrm{CH}_{4}$ production $\left(\mathrm{g} \mathrm{day}^{-1}\right.$ ) with dry matter intake as a percentage of body weight (DMщpBW, \%)

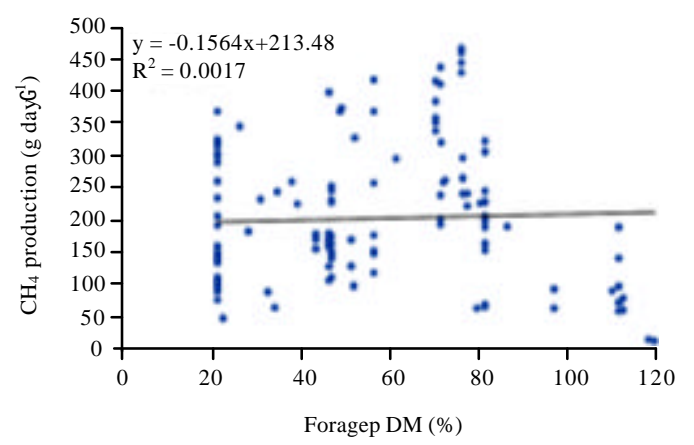

Fig. 5: Relationship of $\mathrm{CH}_{4}$ production $\left(\mathrm{g} \mathrm{day}^{-1}\right.$ ) with the amount of forage as a percentage of dietary dry matter (forage DM, \%)

researchers obtained -24.27 $( \pm 17.76)+13.93( \pm 1.68) \mathrm{DMI}$ $(\mathrm{kg})+0.57( \pm 0.20) \mathrm{FpDM}(\%)+8.43( \pm 4.16) \mathrm{NDFI}(\mathrm{kg})$ $(\mathrm{n}=145,-2$ Res $\log$ likelihood $=1434.9)$ for predicting methane production $(\mathrm{g})$.

Using a simple linear regression, the best equation was $\mathrm{CH}_{4}(\mathrm{~g})=-18.53( \pm 14.90)+11.89( \pm 1.50) \mathrm{DM}(\mathrm{kg})+$ $0.49( \pm 0.18) \mathrm{FpDM}(\%)+14.19( \pm 3.77) \mathrm{NDF}$ intake $(\mathrm{kg})$ $\left(R^{2}=0.84\right.$, root mean square error $\left.=42.25\right)$ even though other possible equations were also derived (Table 3 and Fig. 6). Although, DMI and NDFI are inherently correlated, a single variable was not sufficient to explain the variations in methane production of cattle. When both DMI and NDFI were present in the model type of animal or method of methane measurement was no longer significant. This implies that DMI, NDFI and FpDM can successfully account for the differences in methane production among different stages or types of animals and among different methods (i.e., chamber, SF6 and hood methods). 


\section{J. Anim. Vet. Adv., 11 (17): 3228-3233, 2012}

\begin{tabular}{|c|c|c|c|c|c|}
\hline Variables & $\mathrm{R}^{2}$ & Variable & $\mathrm{R}^{2}$ & Variable & $\mathrm{R}^{2}$ \\
\hline DMI & 0.7674 & DMI, NDFI & 0.8307 & DMI, FpDM, NDFI & 0.8391 \\
\hline NDFI & 0.7493 & DMI, FpDM & 0.8229 & DMI, DMIpBW, NDFI & 0.8318 \\
\hline BW & 0.4782 & DMI, NDF & 0.8149 & BW, DMI, NDFI & 0.8313 \\
\hline DMПpBW & 0.4388 & NDF, NDFI & 0.8106 & DMI, NDF, NDFI & 0.8307 \\
\hline FpDM & 0.0017 & BW, NDFI & 0.7742 & BW, DMI, FpDM & 0.8295 \\
\hline $\mathrm{NDF}$ & 0.0000 & DM!pBW, NDFI & 0.7717 & DMI, DMIpBW, FpDM & 0.8294 \\
\hline - & - & BW, DMI & 0.7704 & DMI, FpDM, NDF & 0.8260 \\
\hline - & - & DMI, DMIpBW & 0.7697 & FpDM, NDF, NDFI & 0.8218 \\
\hline
\end{tabular}

DMI: Dry Matter Intake, NDFI: Neutral Detergent Fiber Intake, BW: Body Weight, DMIpBW: DMI as a percentage of BW, FpDM: Forage as a Percentage of Dietary DM, NDF: Neutral Detergent Fiber Fig. 1. Relationship of $\mathrm{CH}_{4}$ production with Dry Matter Intake (DMI)

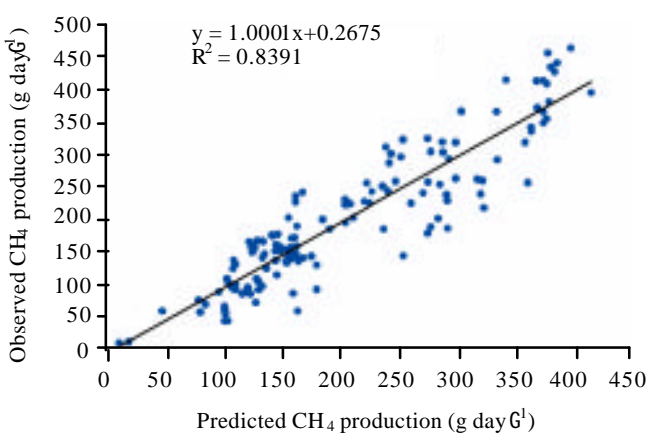

Fig. 6: Regression of observed $\mathrm{CH}_{4}$ production against predicted values.

\section{CONCLUSION}

The results from this study suggest that methane production from cattle can be predicted accurately with DMI and NDFI. More research however is needed to improve accuracy of the model predictions.

\section{ACKNOWLEDGEMENT}

This study was financially supported by research fund of Chungnam National University.

\section{REFERENCES}

Axelsson, J., 1949. The amount of produced methane energy in the European metabolic experiments with adult cattle. Ann. R. Agric. Coll. Sweden, 16: 404-419.

EPA, 2009. Inventory of U.S. greenhouse gas emissions and sinks: 1990-2007. U.S. Environmental Protection Agency, Washington, DC, USA.

Ellis, J.L., E. Kebreab, N.E. Odongo, B.W. McBride, E.K. Okine and J. France, 2007. Prediction of methane production from dairy and beef cattle. J. Dairy Sci., 90: 3456-3466.
Ellis, J.L., E. Kebreab, N.E. Odongo, K. Beauchemin and S. McGinn et al., 2009. Modeling methane production from beef cattle using linear and nonlinear approaches. J. Anim. Sci., 87: 1334-1345.

Garton, B.L. and R.J. Birkenholz, 1998. Global climate change and environmental stewardship by ruminant livestock producers. Proceedings of the 27th National Agricultural Education, December 9, 1998, Washington, DC., USA.

Grainger, C., T. Clarke, S.M. McGinn, M.J. Auldist and K.A. Beauchemin et al., 2007. Methane emissions from dairy cows measured using the sulfur hexafluoride $\left(\mathrm{SF}_{6}\right)$ tracer and chamber techniques. J. Dairy Sci., 90: 2755-2766.

Johnson, K.A. and D.E. Johnson, 1995. Methane emissions from cattle. J. Anim. Sci., 73: 2483-2492.

Kebreab, E., K. Clark, C. Wagner-Riddle and J. France, 2006. Methane and nitrous oxide emissions from Canadian animal agriculture: A review. Can. J. Anim. Sci., 86: 135-157.

Kriss, M., 1930. Quantitative relations of the dry matter of the food consumed, the heat production, the gaseous outgo, and the insensible loss in body weight of cattle. J. Agric. Res., 40: 283-295.

Mills, J.A.N., E. Kebreab, C.M. Yates, L.A. Crompton and S.B. Cammell et al., 2003. Alternative approaches to predicting methane emissions from dairy cows. J. Anim. Sci., 81: 3141-3150.

NRC, 2000. Nutrient Requirements of Beef Cattle. 7th Edn., National Academy Press, Washington, DC., USA.

NRC, 2001. Nutrient Requirements of Dairy Cattle. 7th Edn., National Academies Press, Washington, DC., USA., ISBN: 0309069971, Pages: 381.

Neter, J., M.H. Kutner, C.J. Nachtsheim and W. Wasserman, 1996. Applied Linear Statistical Models. 4th Edn., McGraw Hill, Boston, Massachusetts, ISBN-13: 9780130410207.

Rohweder, D.A., R.F. Barnes and N. Jorgensen, 1978. Proposed hay grading standards based on laboratory analyses for evaluating quality. J. Anim. Sci., 47: 747-759. 
SAS, 2002. User's Guide: Statistics. Version 9.00 Edn., SAS Inst. Inc., Cary, NC, USA.

Seo, S., L.O. Tedeschi, C. Lanzas, C.G. Schwab and D.G. Fox, 2006. Development and evaluation of empirical equations to predict feed passage rate in cattle. Anim. Feed Sci. Technol., 128: 67-83.
Van Soest, P.J., 1994. Nutritional Ecology of the Ruminant. 2nd Edn., Cornell University Press, Ithaca, New York, USA., Pages: 373.

Weiss, W.P., 1993. Predicting energy values of feeds. J. Dairy Sci., 76: 1802-1811. 